\title{
Improving Seed Germination in Mimusops elengi L.
}

\author{
C. Swaminathan*, V. Swaminathan and K. Senthil \\ Department of Agronomy, Agricultural College and Research Institute \\ Tamil Nadu Agricultural University, Madurai - 625104, Tamil Nadu, India \\ *Corresponding author
}

\section{A B S T R A C T}

\begin{tabular}{l} 
Ke y w o r d s \\
$\begin{array}{l}\text { Mimusops elengi, } \\
\text { Germination, } \\
\text { Physical seed } \\
\text { treatment, Chemical } \\
\text { seed treatment, } \\
\text { Organic sources }\end{array}$ \\
\hline Article Info \\
\hline $\begin{array}{l}\text { Accepted: } \\
\text { 26 May 2020 } \\
\text { Available Online: } \\
\text { 10 June 2020 }\end{array}$ \\
\hline
\end{tabular}

Mimusops elengi is commonly planted as an ornamental tree throughout the tropics. Seeds can be stored for 9 months and there is 2000 seeds $/ \mathrm{kg}$. The study was taken up with an objective of enhancing germination in this species through various physical, chemical and organic sources as the main problem of delay in germination in this species as the number of days taken for germination is in a wider range of 17-82 days. The seeds were collected from trees grown in central farm, Agricultural College and Research Institute, Madurai, India, geographically located at $9^{\circ} 54^{\prime} \mathrm{N}$ latitude and $78^{\circ} 54^{\prime \prime}$ E longitude at $147 \mathrm{~m}$ above mean sea level, and were graded in to two categories based on colour of seeds into Black and Brown coloured seeds. Seeds were given treatments including hot and Cold water inundation, Acid scarification, $\mathrm{GA}_{3}$ and organic sources like cow's urine and dung for a specified duration to hasten germination. From the study it is observed that germination in Mimusops elengi can be improved through cold water soaking for 6 hours with a germination percent of more than $80 \%$ and germination in this species started by $33^{\text {rd }}$ day of sowing and continued up to 80 days with a peak on $48^{\text {th }}$ day.

\section{Introduction}

Mimusops elengi is native to India, Sri Lanka, the Andaman Islands, Myanmar, Indo-China and Africa, but is commonly planted as an ornamental tree throughout the tropics. In Asia the heavy, strong and durable wood of Mimusops elengi is well known as suitable for heavy general construction, bridge building, boat and shipbuilding, marine construction, flooring, bearings, doors and framing. It has also been used for poles and piles, foundation sills, railway sleepers, paving blocks, mine timber, furniture and cabinet work, vehicle bodies and wheels, turnery, tool handles, walking sticks, weaving shuttles, toys, sporting goods and musical instruments.

In Africa the wood is considered good for mortars. A good-quality veneer and plywood can be manufactured from the wood. Mimusops elengi also yields a good fuel wood. 


\section{Botany of the species}

It is a evergreen, small to medium-sized tree grows up to $30-40 \mathrm{~m}$ tall; bole up to $100 \mathrm{~cm}$ in diameter, often short and divided into several large main branches but sometimes branchless for up to $15(-20) \mathrm{m}$, buttresses absent or up to $2 \mathrm{~m}$ high; bark surface becoming deeply fissured and sometimes peeling off in thin scales, grey, brown or dark red to blackish, inner bark fibrous, pink or reddish, with scanty watery or white sticky latex; crown dense, rounded and spreading, glossy dark green.

The laves arranged spirally, more or less in tufts at the ends of branches, simple; flowers in fascicles of up to 6 in the leaf axils, bisexual or functionally unisexual, regular, fragrant; Trees may flower and fruit throughout the year. Fruit an ovoid to ellipsoid berry $2-3 \mathrm{~cm}$ long, orange-red when ripe, 1-2-seeded. Seeds up to $2 \mathrm{~cm}$ long, laterally compressed, with small circular basal scar. The germination is epigeal.

Seed can be stored for about 9 months and needs 'after-ripening' during the first month of storage. There are about 2000 dry seeds $/ \mathrm{kg}$. Seed germinates in 17-82 days and the germination rate is $70-90 \%$. It is best sown directly in containers (Martawijaya et al., 1992 and Burkill, 2000).

The study was taken up with an objective of enhancing germination in this species through various physical, chemical and organic sources as the main problem of delay in germination in this species as the number of days taken for germination is in a wider range of 17-82 days.

\section{Materials and Methods}

The seeds were collected from the trees grown in central farm of Agricultural College and Research Institute, Madurai, geographically located at $9^{\circ} 54^{\prime} \mathrm{N}$ latitude and $78^{\circ} 54$ " E longitude at an elevation of $147 \mathrm{~m}$ above mean sea level. The location falls in the Southern agro climatic zone of Tamil Nadu.

The seeds collected were first graded in to two categories based on the colour of the seeds into Black coloured seeds and Brown coloured seeds. The biometric observations like seed length, breadth and weight were recorded and presented in table 1 . Then, for each treatment 100 numbers of both black and brown seeds, were taken and subjected to various treatments as listed below;

Cold water treatment- seed inundation in cold water for 6 hours

Cow's urine $100 \%$ - Seeds were dipped in cow's urine for 30 minutes

Cow's urine $15 \%$ - Seeds were dipped in cow's urine $15 \%$ prepared by mixing of $15 \mathrm{ml}$ of cow's urine in $85 \mathrm{ml}$ of water and soaked for 30 minutes

Cow dung slurry $10 \%$ - Seeds were withered in cow dung slurry, prepared by mixing $10 \mathrm{~g}$ of fresh cow dung in $90 \mathrm{ml}$ of water, for 30 minutes

$\mathrm{GA}_{3}$ 100ppm - Seeds were soaked in GA3 $100 \mathrm{ppm}$ solution for 30 minutes

Acid scarification- Seeds were scarified with concentrated commercial grade sulphuric acid at the rate of $200 \mathrm{ml} / \mathrm{kg}$ of seed for 20 minutes.

Hot water treatment. Seeds were immersed in hot water and allowed to cool for 6 hours.

After treatments, the seeds were sown into polybags of $23 \times 15 \mathrm{~cm}$ size, filled with nursery mixture, on 18.03.2020. The poly bags were watered regularly and the germination of seeds was observed. The data recorded for germination count at the end of the study and presented. 


\section{Results and Discussion}

The germination of Mimusops elengi seed is epigeal. The first germinant in the nursery study was spotted on 21.04.2020 i.e. 33 days after sowing, while peak germination, more number of seeds germinated on a single day in most of the treatments, was observed on $48^{\text {th }}$ day of sowing.

It indicates that the germination in this species bit slow but also has the capacity of germinating in a wide range of days. The data on germination was recorded up to 80 days (07.06.2020) from the date of sowing. As seed germinates in 17-82 days and the germination rate is $70-90 \%$. (Haron, 1998)

The data inferred on the seed weight revealed that black seeds are slightly longer than brown seeds. A perusal of the data on colour of the seed and germination (Table 2); it is observed that brown coloured seeds germinated better than black coloured seeds with a mean value of 50.3 percent.

Considering the treatments maximum germination was observed with Coldwater treatment for 6 hours in both with the values of more than 80 percent. Followed by, treating the seeds with cow dung slurry which ensures more than 60 percent germination.

Acid scarification and hot water did not promote germination, while withering with cow's urine improved germination. While Swaminathan and Swarnapria (2001) reported that inundating seeds of tree species with hot water enhanced germination and related attributes. Germination increased by five folds in Acacia crassicarpa and six folds in Acacia mangium. Inundating seeds with cold water showed a poor germination of only $15 \%$.
In this study, GA3100ppm failed to influence germination.

On contrary, Gami et al., (2010) reported that Seed germination was observed in media fortified with IBA, Kn, BA and GA. The reason may be attributed to the age of tree at the time of collection, geographical and agroclimatic conditions prevailing in the site of collection.

Cow urine contains about 1.0\% Nitrogen traces of $\mathrm{P} 2 \mathrm{O} 5$ and $1.0 \%$ of $\mathrm{K} 2 \mathrm{O}$. Bovine urines contain growth regulators, nutrients, trace element. Organic seeds treatment is more affordable so even small scale farmers can practice. It could be concluded that, cow urine $(5 \%)$ can be recommended as organic pre-sowing seed treatment for increasing the vigour in coarse cereals and paddy (Ambika et al., 2014)

The position of the seed in the pod as well tree may also have effect on germination and seedling establishment (Srimathi et al., 1992) and also position of the seed while sowing as observed by Swaminathan et al., (1993) in pungam and they reported that sowing the seeds vertically with the micropyle directed downwards gave the maximum germination of $92 \%$.

Vertical sowing with the micropyle oriented laterally and upwards recorded respectively germinability of 58 and $66 \%$. Sowing the seeds flat gave germination of $72 \%$ indicating that micropyle orientation is more important than disposition of seed vertically or flat.

Further, a detailed study on the seed grading based on colour, locations and agro climatic zones on germination would be interesting and fruitful for future research. 
Table.1 Seed attributes of Mimusops elengi

\begin{tabular}{|l|l|l|}
\hline Parameter & Brown color seed & Black color seed \\
\hline Seed length & $1.77^{\#} \pm 0.00840^{*}$ & $1.77 \pm 0.00851$ \\
\hline Seed breadth & $1.08 \pm 0.710$ & $1.13 \pm 0.659$ \\
\hline Seed weight & $0.41+0.00048$ & $0.42+0.00052$ \\
\hline
\end{tabular}

\# mean values of 100 seeds $\quad *$ Standard error

Table.2 Seed Germination percentage (\%)

\begin{tabular}{|l|l|c|c|c|}
\hline SI no. & Treatments & Brown color seed & Black color seed & Mean \\
\hline $\mathbf{1}$ & Cold water & 82 & 80 & 81.0 \\
\hline $\mathbf{2}$ & Cow's urine @ 100\% & 62 & 40 & 51.0 \\
\hline $\mathbf{3}$ & Cow's urine @ 15\% & 46 & 50 & 48.0 \\
\hline $\mathbf{4}$ & Cow Dung slurry 10\% & 82 & 60 & 71.0 \\
\hline $\mathbf{5}$ & GA3 100ppm & 22 & 20 & 21.0 \\
\hline $\mathbf{6}$ & Acid scarification & 31 & 40 & 35.5 \\
\hline $\mathbf{7}$ & Hot water & 27 & 25 & 26.0 \\
\hline & Average & 50.3 & 45.0 & \\
\hline & F Test & & & \\
\hline & T Test & & 0.649 & \\
\hline & Standard Deviation & 25.4 & & \\
\hline & Mean & 54.2 & 48.3 & \\
\hline & CV $(\%)$ & 47.0 & 43.3 & \\
\hline
\end{tabular}

From the study it could be concluded that germination in Mimusops elengi can be improved through cold water soaking for 6 hours with a germination percent of more than $80 \%$ and the germination in this species started by $33^{\text {rd }}$ day of sowing and continued up to 80 days with a peak on $48^{\text {th }}$ day.

\section{References}

Ambika, S., K. Balakrishnan and K. Sujatha. 2014. Enhancing the Seed Germination and Vigour in Coarse Cereals by Bovine Urines. Journal of Agroecology and Natural Resource Management. Vol. 1(2): 40-43

Burkill, H.M., 2000. The useful plants of West Tropical Africa. 2nd Edition. Volume 5, Families S-Z, Addenda.
Royal Botanic Gardens, Kew, Richmond, United Kingdom. 686 pp.

Gami,B., M. Parabia and I.L. Kothari. 2010. Pretreatment Effects on Germination of Mimusops elengi L. Seed Technology Vol. 32 (2): 138-144

Haron, N.W.1998. Mimusops L. In: Sosef, M.S.M., Hong, L.T. \& Prawirohatmodjo, S. (Eds). Plant Resources of South-East Asia No 5(3). pp. 382-385. In Timber trees: Lesserknown timbers. Backhuys Publishers, Leiden, Netherlands..

Martawijaya, A., Kartasujana, I., Kadir, K. and Prawira, S.A., 1992. Indonesian wood atlas. Pp. 168. In Volume 2. Forest Products Research and Development Centre, Bogor, Indonesia. Srimathi, P., C. Swaminathan, K. Sivagnanam 
and Surendran, P., 1992. Seed attributes in relation to their position in the pod and its influence on seedling establishment of four ornamental tree species. Journal of Tropical Forest Science, 4(3): 245-248

Swaminathan, C. and R. Swarnapiria. 2001 Improving germination in two
Australian acacias Journal of Tropical Forest Science. 13(2): 364-368

Swaminathan, C., R.S. Vinaya Rai and K. Sivagnanam. 1993. Improving seed germination of Derris indica by vertical sowing. Journal of Tropical Forest Science, 6(2): $152-158$.

\section{How to cite this article:}

Swaminathan, C., V. Swaminathan and Senthil, K. 2020. Improving Seed Germination in Mimusops elengi L. Int.J.Curr.Microbiol.App.Sci. 9(06): xx-Xx.

doi: https://doi.org/10.20546/ijcmas.2020.906.443 